Aim of the study: Recent investigations have taken into account the role of mast cells in prostate cancer formation, analyzing their dual functions (as tumour growth promoters and tumour growth inhibitors). The aim of our study was to compare mast cell infiltration and microvessel density in prostate cancer and in benign prostate hyperplasia. We also attempted to find possible relationships among mast cell infiltration and microvessel density, Gleason score, as well as serum levels of prostate-specific antigen (PSA).

Material and methods: The investigation was confined to evaluations of material from prostate needle biopsies, carried out in 26 patients with prostate cancer, and of 14 specimens diagnosed as benign hyperplasia. The numbers of tryptase positive mast cells and CD34 positive vessels were determined using a computer image analysis system. In the patients with prostate cancer, both mast cell infiltrates and microvessel density were significantly increased, as compared to the control patients. Results: Significant positive correlations were identified between the mean numbers of mast cells and microvessel densities, both in the prostate cancer group and in the control group. Moreover, significant positive correlations were observed between Gleason score on one hand and the number of mast cells and microvessel density on the other. The correlations between PSA serum levels and both mast cell infiltration and microvessel density were positive, but not in a statistically significant way. Conclusions: The reported investigations may support the assumption of mast cell promoter function in prostate cancer development, whereas no evidence was found for their opposite

Key words: prostate cancer, microvessel density, mast cells.

Contemp Oncol (Pozn) 2013; 17 (4): 378-382 DOI: $10.5114 /$ wo.2013.37220

\section{Augmented mast cell infiltration and microvessel density in prostate cancer}

\author{
Paweł Stawerski ${ }^{1}$, Małgorzata Wagrowska-Danilewicz, \\ Olga Stasikowska-Kanicka1, Elżbieta Tuka², Marian Danilewicz ${ }^{3}$
}

1Department of Nephropathology, Medical University of Lodz, Lodz, Poland 2Department of Pathology, Voivodeship Hospital, Skierniewice, Poland ${ }_{3}^{3}$ Medical University of Lodz, Lodz, Poland

\section{Introduction}

Prostate cancer is the most threatening and very often fatal malignancy in elderly men. There are over 540,000 new cases diagnosed each year worldwide [1]. The mortality rate associated with prostate carcinoma ranks second in Poland and first in the USA [2]. Searching for new methods of cancer therapy and prognosis is a key task for many researchers around the world.

The classic, widely used prognostic factors for prostate cancer include the prostate-specific antigen (PSA) levels in serum, histological grading - Gleason score - and clinical staging, using the TNM (tumour-node-metastasis) system. Some investigations, carried out during recent years, have taken into account other important prognostic factors, such as mast cell infiltration and their influence on tumour angiogenesis [3-6].

Neoplastic proliferation is almost always accompanied by inflammatory infiltrates: neutrophils, lymphocytes, macrophages and mast cells. The mast cells play an important role in growth regulation of many tumours. One of these tumours is prostate cancer, but the role of mast cells in this particular tumour is a rather controversial issue. Mast cells belong to inflammatory regulators. Inflammation is a defence line against tumour, and inflammatory infiltrates may lead to better outcomes in tumour-affected patients. On the other hand, mast cells produce many bioactive mediators and growth factors, including fibroblasts and angiogenic growth factors, such as FGF-2 (fibroblast growth factor-2), VEGF (vascular endothelial growth factor), TGF- $\beta$ (transforming growth factor $\beta$ ) and IL-8 (interleukin-8) [3]. These mediators play a crucial role in promoting tumour angiogenesis and metastasis, and thus are associated with poor prognosis for affected patients. Also mast cells produce proteolytic enzymes, e.g., specific tryptase and matrix metalloproteinases (MMP-2, MMP-9) [4], which may facilitate cancer stromal invasion.

The angiogenic potential of mast cells, indicated in some studies [3-9], is reflected by increased microvessel density in prostate cancer.

In view of the above-mentioned observations, the aim of our study was to compare mast cell infiltration and microvessel density, as expressed by CD-34 immunoreactivity, in prostate cancer formation and in benign prostate hyperplasia. We also attempted to find possible relationships among mast cell infiltration and microvessel density, Gleason score and serum PSA levels.

\section{Material and methods}

\section{Patients}

The investigation was confined to evaluations of materials from prostate needle biopsies, carried out in 26 patients, diagnosed at the Provincial Hospital in Skierniewice, Poland, during the years 2008-2010. In all the cases, elevated serum PSA levels indicated the need of biopsy. The mean \pm SD (standard deviation) age of the patients was $69.95 \pm 6.22$ years, PSA levels varied from $4.03 \mathrm{ng} / \mathrm{ml}$ to $100 \mathrm{ng} / \mathrm{ml}$, and the mean PSA level was $37.47 \pm 32.32$. Gleason score varied from 4 to 9 . All the patients of that group were diagnosed 
with prostate cancer, using light microscopy and the standard haematoxylin-eosin staining method. Fourteen specimens of prostate gland, diagnosed as benign hyperplasia, were used as controls. In all the control patients, serum PSA levels of PSA were within normal limits (from $0.9 \mathrm{ng} / \mathrm{ml}$ to $3.9 \mathrm{ng} / \mathrm{ml}$, mean $2.2 \pm 1.8$ ).

\section{Immunohistochemistry}

Paraffin-embedded tissue sections were mounted onto SuperFrost slides, deparaffinised, treated in a microwave oven with a solution of TRS (Target Retrieval Solution, pH 6.0, Dao) for 30 minutes $(2 \times 6$ minutes $360 \mathrm{~W}, 2 \times 5$ minutes $180 \mathrm{~W}, 2 \times 4$ minutes $90 \mathrm{~W}$ ) and transferred to distilled water. Endogenous peroxidase activity was blocked by $0.3 \%$ hydrogen peroxide in distilled water for 30 minutes and then the sections were rinsed with Tris-buffered saline (TBS, Dako, Denmark) and incubated for 30 minutes with primary mouse monoclonal antibodies against mast cell tryptase (Dako; clone AA1, dilution 1: 50) and CD34 antigen (Dako; clone QBend10, dilution 1 : 25). Immunoreactive proteins were visualized using an EnVision-HRP kit (Dako, Carpinteria, CA, USA), according to the manufacturer's instructions. Visualisation was performed by incubation of the sections in a solution of 3,3'-diaminobenzidine (DakoCytomation, Denmark). After washing, the sections were counter-stained with haematoxylin and coverslipped. A negative control was processed for each antibody and for each sample. Negative controls were carried out by incubation in the absence of the primary antibody and always yielded negative results.

\section{Morphometry}

Histological morphometry was performed by means of an image analysis system, including a PC with a Pentagram graphical tablet, an Indeo Fast card (frame grabber, true-colour, real-time), produced by Indeo (Taiwan), and a Panasonic colour TV camera (Japan), coupled with a Carl Zeiss microscope (Germany). On that hardware the (MultiScan 8.08 program of Computer Scanning Systems, Poland) was installed to calculate the number of objects (semiautomatic function). The colour microscopic images were serially saved in the computer memory, followed by quantitative examinations. The numbers of tryptase-positive mast cells and of CD34-positive vessels were determined by counting all the positive cells and vessels (semiautomatic function) in a sequence of ten consecutive computer images of $400 \times$ high power fields $0.0047 \mathrm{~mm}^{2}$ each. Only vessels with an evident lumen were counted. Mast cells were scored positive when displayed cytoplasmic granules stained positively with anti-tryptase monoclonal antibody. The results were expressed as the mean number of immunopositive cells or vessels per $\mathrm{mm}^{2}$.

Table 1. Quantitative data of mast cell infiltrates and microvessel density in prostate cancer and controls

\begin{tabular}{|lccc|}
\hline $\begin{array}{l}\text { Number } \\
\text { of cases }\end{array}$ & $\begin{array}{c}\text { Controls } \\
(n=14)\end{array}$ & $\begin{array}{c}\text { Prostate cancer } \\
(n=26)\end{array}$ & $P$ value \\
\hline Mast cells (per $\left.1 \mathrm{~mm}^{2}\right)$ & $72.82 \pm 55.6$ & $123.73 \pm 82.32<0.05$ \\
\hline Microvessel density* & $67.72 \pm 28.5$ & $179.43 \pm 72.52<0.001$ \\
\hline
\end{tabular}

*Microvessel density as mean number of CD34-positive vessels per $1 \mathrm{~mm}^{2}$

\section{Statistical methods}

All the obtained values were expressed as means \pm SD. Differences between groups were tested by the Mann-Whitney $U$ test. Correlation coefficients were calculated by Spearman's method. Results were considered statistically significant if $p<0.05$.

\section{Results}

Table 1 presents quantitative data of mast cell infiltration and of microvessel density for the patients with prostate cancer and for the controls. Regarding the former, both mast cell infiltrates and microvessel density (MVD) were significantly increased, when compared to respective values in the control patients (Figs. 1-4). Furthermore, our correlative study (see Table 2) revealed significant positive correlations between the mean number of mast cells and microvessel density both in the group with prostate cancer and in the control group. In the patients with prostate cancer, significant positive correlations were observed between the mean number of tryptase-positive cells and Gleason score, as well as between microvessel density and Gleason score. The correlations between the number of mast cells and PSA levels and between microvessel densities and PSA levels were positive but they did not reach statistical significance. In the controls, those correlations were weak and not significant, either.

\section{Discussion}

In our investigations, we tried to unveil the role of mast cell infiltration in the progression of prostate cancer and its associations with classic prognostic factors, such as Gleason score and serum PSA levels. An increase of mast cell infiltration and microvessel density was observed in the patients with prostate cancer, as compared to those with benign hyperplasia. That finding suggests a stimulating role of mast cells in tumourigenesis, resulting from the angiogenic activity of mast cells. Enhanced angiogenesis is associated with degranulation of mast cells, which releases biological mediators, including the regulators of vascular functions, such as FGF-2, VEGF and TGF- $\beta[10,11]$. The formation of new vasculature is a crucial process for tumour growth and progression. One of the major regulators in this process is VEGF,

Table 2. Correlations between selected parameters in prostate cancer and controls

$\begin{array}{lcc}\begin{array}{l}\text { Correlation : } \\ \text { between }\end{array} & \begin{array}{c}\text { Controls } \\ (n=14)\end{array} & \begin{array}{c}\text { Prostate cancer } \\ (n=26)\end{array} \\ \begin{array}{l}\text { Mast cells and microvessel } \\ \text { density }\end{array} & \begin{array}{l}r=0.54, \\ p<0.05\end{array} & \begin{array}{c}r=0.64, \\ p<0.005\end{array} \\ \text { Mast cells and PSA level } & r=0.24, & r=0.35, \\ & p=0.42 \text { (NS) } & p=0.079 \text { (NS) } \\ \text { Mast cells and Gleason } & - & r=0.63, \\ \text { score } & & p<0.001 \\ \text { Microvessel density } & r=0.14, & r=0.19, \\ \text { and PSA level } & p=0.63 \text { (NS) } & p=0.35 \text { (NS) } \\ \text { Microvessel density } & - & r=0.48, \\ \text { and Gleason score } & - & p<0.02\end{array}$

NS - not significant 


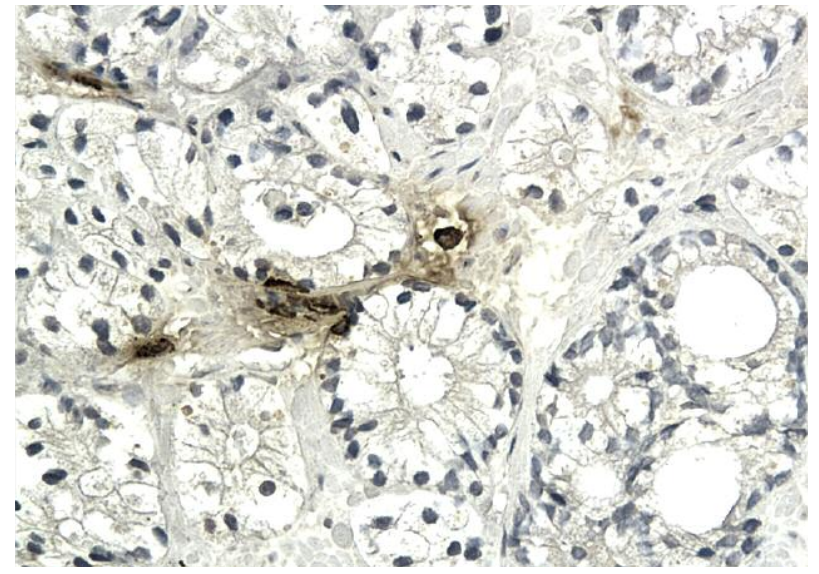

Fig. 1. Scanty mast cell infiltrates in benign prostate hyperplasia. Magnification 400x

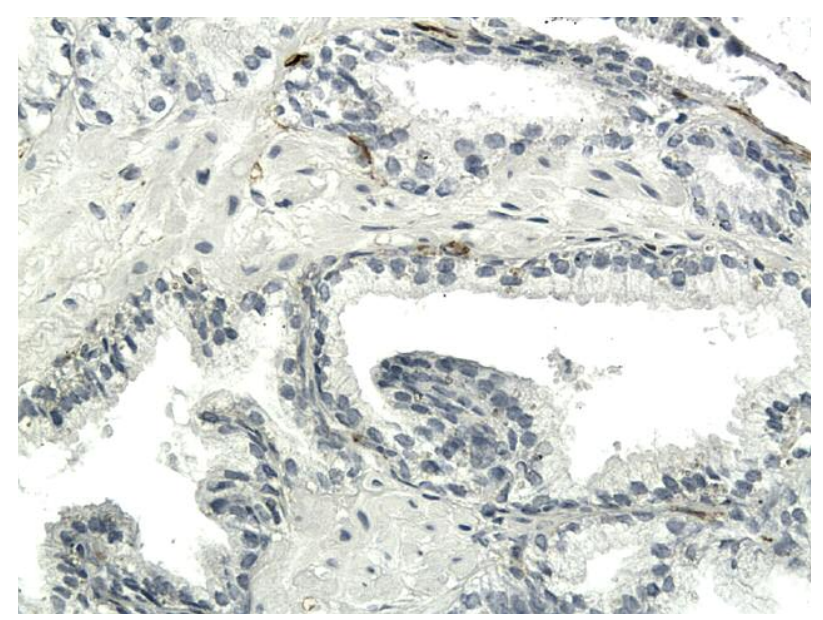

Fig. 3. Microvessel density in benign prostate hyperplasia. Only a few CD 34 positive vessels can be seen. Magnification 400x

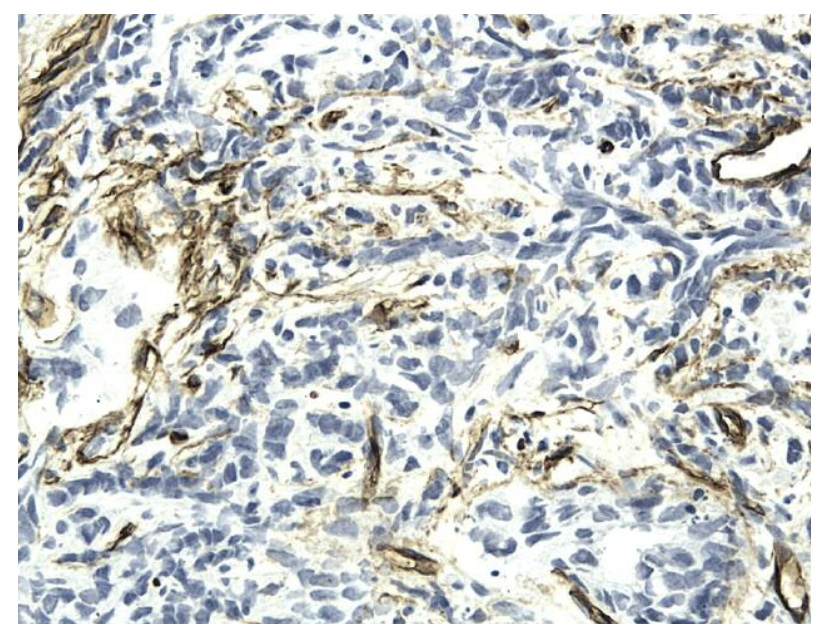

Fig. 4. Increased microvessel density in prostate cancer. Magnification $400 \times$

secreted, among others, by mast cells [8, 11]. Vascular endothelial growth factor is a homodimeric glycoprotein, taking part in many normal processes, such as embryonic devel-

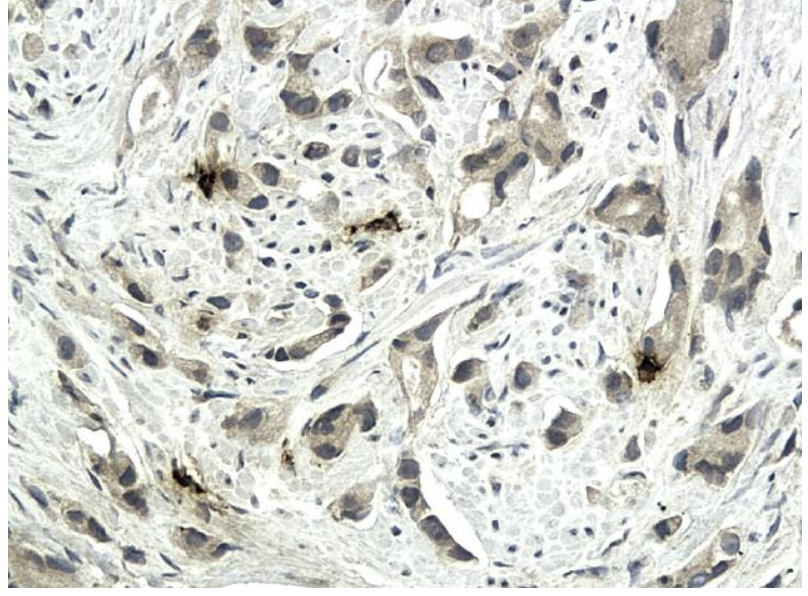

Fig. 2. Numerous mast cells in prostate cancer. Magnification $400 x$

opment, somatic growth and wound healing. Vascular endothelial growth factor stimulates mainly the growth of endothelial cells but also endothelial cell mitogenesis and cell migration [12, 13]. However, VEGF is not the only angiogenesis-stimulating factor. Mast cells secrete chymase and tryptase and these proteins act as degradation factors for extracellular matrix. Moreover, a mast cell also produces metalloproteinases, such as MMP-2 and MMP-9, which demonstrate pro-angiogenic potential by their ability to break down extracellular matrix $[10,14,15]$. Histamine, one of the main and characteristic products of mast cells, increases permeability of capillaries.

Mast cell products not only support the progression of prostate cancer but their role is also observed in other tumours, e.g., colorectal cancer [16, 17], renal cell carcinoma [18] or pulmonary cancer [19]. Moreover, the mediators released by degranulated mast cells promote metastasis of these malignant tumours. The proteolytic enzymes tryptase and metalloproteinases (MMP-2 and MMP-9) - promote cancer cell invasion into stromal tissues by degrading the extracellular matrix $[14,15]$. All of the above-mentioned mechanisms may suggest a tumour promoting role of mast cells. Tumour growth is promoted by multiple mechanisms with angiogenesis being one of the major ones. This process can be evaluated by assessing microvessel density, taking into account the immunoreactivity of endothelial cells with CD34 antibody. In our study, microvessel density in prostate cancer correlated positively with the intensity of mast cell infiltration, as well as with Gleason score. The correlation between mast cell infiltration and microvessel density is widely reported [3-10]. In our study, MVD was observed as 67.72 CD34 positive vessels per $1 \mathrm{~mm}^{2}$ in benign lesions and 179.43 vessels in prostate cancer. The mast cell density was 72.82 and 123.73 , respectively. Similar observations were made by Nonomura [5], who found a positive correlation between the number of mast cells around cancer foci and Gleason score, also with clinical outcome. Nassif [4] stated that angiogenesis, expressed as a microvessel count, is augmented in prostate cancer, as compared to benign hyperplasia. He also found a positive correlation between MVD and PSA serum levels, indicating a higher risk of cancer recurrence in postoperative patients with high MVD 
values. It is noteworthy that, in our study, this correlation was weak and not significant. Similar findings were reported by a number of authors $[6,11,20]$. Ahmadi [21] found differences in microvessel density between low grade (109 vessels/mm²) and high-grade prostate cancer (168 vessels $/ \mathrm{mm}^{2}$ ). Such relationships between the number of mast cells and MVD are observed not only in prostate cancer. Tana et al. [18] found this positive correlation in renal cancer. Moreover, these relationships were found in colorectal cancer, breast cancer and oral squamous cell carcinoma. The opposite opinions are not very strong. Mohseni et al. [22] found no associations between mast cell density, angiogenesis and clinicopathological parameters of renal cell carcinoma. Also, no relationship between MVD and Gleason score was found in prostate cancer by Motta [23].

Johannson et al. presented an interesting observation in 2010 [3]. They found a difference in the functionality of mast cells within the tumour, compared to that in the peritumoural region. The mast cells, located within the tumour, inhibited angiogenesis, while peritumoural mast cells promoted it, stimulating tumour growth. Those findings correlated with patients' clinical outcomes and treatment responses. Johannson's observations corresponded to the dual role of mast cells in tumourigenesis. They act as "pro and against" cells, simultaneously promoting and inhibiting tumour development, the effects possibly depending on their location, i.e., either intra- or peritumoural. Similar observations were reported by Dyduch et al. [7]. The anti-tumour function of mastocytes was proven by Aydin et al. [24], Fleischmann et al. [25] and Pittoni et al. [26]. Also Dyduch et al. in another study [27] observed a smaller count of mast cells in melanomas of the skin than in benign nevi. These authors indicate an ability of mast cells to induce fibrotic processes, which confirms their role in triggering inflammatory processes. Mast cells secrete many bioactive mediators, such as histamine, prostaglandins, cytokines or leukotriene $\mathrm{C4}$, which take part in the immunological hostdefence reaction against tumour growth [28]. No evidence was found in our study for mast cell infiltration in prostate cancer. It should be noted, however, that our biopsy specimens were rather small and contained mainly prostate cancer material, while materials from the peritumoural region were scarce and sporadic. This fact did limit the evaluation of the role of mast cells in the peritumoural area.

In conclusion, our investigations may suggest a promoter function of mast cells in prostate cancer formation and development, whereas no evidence was found for their opposite activity. As the concept of dual function of tryptase-positive cells is still a fairly interesting issue, it needs further studies on larger post-operative specimens to get a better understanding of neoplastic processes in the prostate gland, while also searching for improved and more effective therapy protocols for patients suffering from prostate cancer.

The authors declare no conflict of interest.

\section{References}

1. Schröder FH. Screening for prostate cancer. Urol Clin North Am 2003; 30: 239-51.

2. Dobruch J, Borówka A, Antoniewicz A, Chłosta P. Epidemiologia raka gruczołu krokowego: zmiany obserwowane w Polsce w latach 19912000. Urol Pol 2005; 58: 1.

3. Johansson A, Rudolfsson S, Hammarsten P, et al. Mast cells are novel independent prognostic markers in prostate cancer and represent a target for therapy. Am J Pathol 2010; 177: 1031-41.

4. Nassif AE, Tâmbara Filho R. Immunohistochemistry expression of tumour markers CD34 and P27 as a prognostic factor of clinically localized prostate adenocarcinoma after radical prostatectomy. Rev Col Bras Cir 2010; 37: 338-44.

5. Nonomura N, Takayama H, Nishimura K, et al. Decreased number of mast cells infiltrating into needle biopsy specimens leads to a better prognosis of prostate cancer. Br J Cancer 2007; 97: 952-6.

6. Bono AV, Celato N, Cova V, Salvadore M, Chinetti S, Novario R. Microvessel density in prostate carcinoma. Prostate Cancer Prostatic Dis 2002; 5: 123-7.

7. Dyduch G, Kaczmarczyk K, Okoń K. Mast cells and cancer: enemies or allies? Pol J Pathol 2012; 63: 1-7.

8. Yang J, Wu HF, Qian LX, et al. Increased expressions of vascular endothelial growth factor (VEGF), VEGF-C and VEGF receptor-3 in prostate cancer tissue are associated with tumour progression. Asian J Androl 2006; 8: 169-75.

9. de la Taille A, Katz AE, Bagiella E, et al. Microvessel density as a predictor of PSA recurrence after radical prostatectomy. A comparison of CD34 and CD31. Am J Clin Pathol 2000; 113: 555-62.

10. Blair RJ, Meng H, Marchese MJ, Ren S, Schwartz LB, Tonnesen MG, Gruber BL. Human mast cells stimulate vascular tube formation. Tryptase is a novel, potent angiogenic factor. J Clin Invest 1997; 99 : 2691-700.

11. Stefanou D, Batistatou A, Kamina S, Arkoumani E, Papachristou DJ, Agnantis NJ. Expression of vascular endothelial growth factor (VEGF) and association with microvessel density in benign prostatic hyperplasia and prostate cancer. In Vivo 2004; 18: 155-60.

12. Holmes K, Roberts OL, Thomas AM, Cross MJ. Vascular endothelial growth factor receptor-2: structure, function, intracellular signalling and therapeutic inhibition. Cell Signal 2007; 19: 2003-2012.

13. Cébe Suarez S, Pieren M, Cariolato, L et al. A VEGF-A splice variant defective for heparan sulfate and neuropilin-1 binding shows attenuated signaling through VEGFR-2. Cell Mol Life Sci 2006; 63: 2067-77.

14. Rundhaug JE. Matrix metalloproteinases and angiogenesis. J Cell Mol Med 2005; 9: 267-85.

15. Lafleur MA, Handsley MM, Edwards DR. Metalloproteinases and their inhibitors in angiogenesis. Expert Rev Mol Med 2003; 22: 1-39.

16. Abdou AG, Aiad H, Asaad N, Abd El-Wahed M, Serag El-Dien M. Immunohistochemical evaluation of vascular endothelial growth factor (VEGF) in colorectal carcinoma. J Egypt Natl Canc Inst 2006; 18: 311-22.

17. Gulubova M, Vlaykova T. Prognostic significance of mast cell number and microvascular density for the survival of patients with primary colorectal cancer. J Gastroenterol Hepatol 2009; 24: 1265-75.

18. Tuna B, Yorukoglu K, Unlu M, Mungan MU, Kirkali Z. Association of mast cells with microvessel density in renal cell carcinomas. Eur Urol 2006; 50: 530-4.

19. Takanami I, Takeuchi K, Naruke M. Mast cell density is associated with angiogenesis and poor prognosis in pulmonary adenocarcinoma. Cancer 2000; 88: 2686-92.

20. Arakawa A, Soh S, Chakraborty S, Scardino PT, Wheeler TM. Prognostic significance of angiogenesis in clinically localized prostate cancer (staining for Factor VIII-related antigen and CD34 antigen). Prostate Cancer Prostatic Dis 1997; 1: 32-8.

21. Ahmadi SA, Moinfar M, Gohari Moghaddam K, Bahadori M. Practical application of angiogenesis and vasculogenic mimicry in prostatic adenocarcinoma. Arch Iran Med 2010; 13: 498-503.

22. Mohseni MG, Mohammadi A, Heshmat AS, Kosari F, Meysamie AP. The lack of correlation between mast cells and microvessel density with pathologic feature of renal cell carcinoma. Int Urol Nephrol 2010; 42: 109-12.

23. da Motta VP, Malafaia O, Ribas-Filho JM, Czeczko NG, Ribas CA, Cuenca RM. CASPASE-3 and CD-34 expression in prostate adenocarcinoma. Rev Col Bras Cir 2009; 36: 223-9. 
24. Aydin O, Dusmez D, Cinel L, Doruk E, Kanik A. Immunohistological analysis of mast cell numbers in the intratumoral and peritumoral regions of prostate carcinoma compared to benign prostatic hyperplasia. Pathol Res Pract 2002; 198: 267-71.

25. Fleischmann A, Schlomm T, Köllermann J, et al. Immunological microenvironment in prostate cancer: high mast cell densities are associated with favorable tumour characteristics and good prognosis. Prostate 2009; 69: 976-81.

26. Pittoni P, Colombo MP. The dark side of mast cell-targeted therapy in prostate cancer. Cancer Res 2012; 72: 831-5.

27. Dyduch G, Okoń K, Pescarini E. Mast cells in melanocytic skin lesions. An immunohistochemical and quantitative study. Pol J Pathol 2011; 62: 139-44.

28. Prussin C, Metcalfe DD. IgE, mast cells, basophils, and eosinophils. J Allergy Clin Immunol 2003; 111: 486-94.

\section{Address for correspondence}

Paweł Stawerski MD, PhD

Department of Nephropathology

Medical University of Lodz

Pomorska 251

92-213 Łodz, Poland

e-mail: paulost@me.com

Submitted: 17.10 .2012

Accepted: 27.11.2012 